\title{
Providing Help in Hard Times: A Blueprint for Successful Strategic Planning
}

\section{William Buck}

To cite this article: William Buck (2016) Providing Help in Hard Times: A Blueprint for Successful Strategic Planning, Journal of Library Administration, 56:2, 199-208, DOI: 10.1080/01930826.2015.1124703

To link to this article: https://doi.org/10.1080/01930826.2015.1124703

册Published online: 12 Feb 2016.

Submit your article to this journal $\pi$

III Article views: 1450

Q View related articles $₫$

View Crossmark data $₫$ 


\title{
Strategic Planning and Assessment
}

\author{
WANDA V. DOLE, Column Editor \\ Emeritus Dean of the Library, University of Arkansas at Little Rock, Little Rock, AR, USA \\ Texas State Library \& Archives Commission, Talking Book Program, Austin, TX, USA
}

Column Editor's Note. This column focuses on the closely related topics of strategic planning and assessment in all types of libraries. The column examines all aspects of planning and assessment including (but not limited to) components, methods, approaches, trends, tools and training. Interested authors are invited to submit articles to the editor at wvdole@ualr.edu. Articles on both theory and practice and examples of both successful and unsuccessful attempts in all types of libraries are invited.

In this issue, William Buck examines the literature about the impact of the Great Recession of 2007-2009 and provides a blueprint for library administrators facing the challenges of increased user demand and static or decreased funding. Although be is writing from a public library perspective, he provides guidelines useful for libraries of all types. Mr. Buck has spent over 25 years in academic and special collections libraries and has extensive experience with circulation, reference, and information retrieval services. He received a Bachelor's degree in History from the University of Texas at Austin and a Master's degree with academic certificate in library management from the University of North Texas. He currently works in the talking book program of the Texas State Library and Archives Commission providing support to special needs patrons. He writes on library issues and lives in Austin, Texas.

\section{PROVIDING HELP IN HARD TIMES: A BLUEPRINT FOR SUCCESSFUL STRATEGIC PLANNING}

\author{
WILLIAM BUCK \\ Texas State Library \& Archives Commission, Talking Book Program, Austin, TX, USA
}

(c) William Buck

Address correspondence to William Buck, Texas State Library \& Archives, Talking Book Program, 4400B Shoal Creek Blvd., Austin, TX 78756, USA. E-mail: williambuck@my.unt.edu 


\begin{abstract}
In response to a lack of funding during the 2007-2009 recession, many library systems reduced or eliminated professional and library support positions. Traditional outcome measurements were not sufficient to convince tax-depleted legislatures to allocate more funds to libraries. In response to the crisis authors recommended cost-saving measures and tactics for perception management. Studies have shown that the demand for library services increases during times of economic hardship. The production of a strategic plan justifying budget requests is necessary in those times, and should be accompanied by efforts to secure endowment and donation opportunities. This column provides a table or "blueprint for successful strategic planning" that matches goals, actions and measurement criteria.
\end{abstract}

KEYWORDS libraries, U.S., Great Recession, strategic planning, blueprint, budgets

\title{
INTRODUCTION
}

In recent years library professionals have been forced to deal with across the board budget cuts. In doing so they have had to make compromises in their budgeting plans while at the same time taking into account staffing and morale concerns. Although conditions are currently improving, in the immediate aftermath of the recession there were reports of national losses for both professional and library support staff. This was due to cost-cutting measures by administrators and staff dismissals recommended by private consulting firms (Kelly, 2011). The reductions occurred at a time when the workforce was more multi-generational and multi-ethnic than ever before. Library planners have adopted various strategies to offset negative outcomes, from developing information training programs to offering technical suggestions about building maintenance. Despite sobering evidence of past fiscal austerity, there are strong indications that library planning is on the verge of a resurgence. This essay presents a selection of responses by scholars to the recession and provides a goals, actions, and success criteria table to justify a library's budget request. The importance of marketing and funding research is also considered.

Successful navigation of an organization through a difficult period of change requires an appreciation for structural complexity. Library management in particular can be understood by reference to various levels, such as the operational, which controls routine daily functions, and the tactical, which deals with the allocation and use of resources. The most important level for a library facing the prospect of budget reductions is the strategic, which determines the various responses to the external environment. What 
makes long-term planning difficult is the volatility of local governments and their budgeting mechanisms. Since there are political parties and groups that are in principle opposed to most public expenditures, the library will always have to justify the utility of its existence. During times of serious budget shortfalls, simple circulation and reference counts, as well as other traditional outcome measurements will not be sufficient to justify continued funding. Most importantly, they do not adequately show the impact that the library's services have had on a patron's goals and quality of life. Although the current Library Journal budget survey shows an increase in materials, operations, and salary budgets for $73 \%$ of responding libraries regardless of size, common sense and experience would suggest that the policy of simply relying on the continued support of elected officials who are constantly changing is an ineffective one (Peet, 2015). The most effective strategy for library administrators is to have a justification of goals document prepared in advance for lean economic times, in particular a justification that shows how such times directly increase the need for library services.

\section{SCHOLARS RESPOND}

A number of thoughtful and instructive articles have been written in response to the challenges brought about by the recession. Michael Kelly reports that Library Journal's annual budget survey for 2010 reads like "scanning a battlefield." Finance-starved government officials cut libraries first, in order to have money for "essential" services. Among libraries serving populations above one million (urban center libraries) 86\% reported budget cuts and 93\% reduced staff (Kelly, 2011). Kelly compares various states and various population centers to judge the community support of libraries in those areas. Accordingly, 43\% of respondents reported a decrease in the number of salaried positions, with 85.7 full-time employees lost in 2009 and 82 full-time employees lost in 2010. Kelly provides three tables of data: budget trends, perception of political support, and change in number of staff over the last year. The tables show that libraries reporting no change in staffing were also the smallest, usually consisting of one full-time professional and a few student workers. Kelly notes that LSSI (Library Systems \& Services), the private company hired by library systems in California to help manage their budgets, cut many professional staff positions and replaced them with support staff. Although some librarians were rehired, LSSI does not provide pensions to employees (Strietfield, 2010). Not surprisingly, many in the profession have criticized a solution of this type.

Betha Gutsche (2011) reports that during the economic downturn library staff were often the first responders for many people who had lost their jobs, some of whom were experiencing considerable anxiety and confusion. She cites the OCLC Perceptions of Libraries (2010) study, which reported that 37\% 
of library patrons used the library's services more often during the recession (Gutsche, 2011). She points out that state and public library responses to workforce recovery have been documented in Project Compass; Libraries lead the Workforce in the 21st Century. Some examples include:

- Pasco County Library System, Florida, created the E-government Tools page;

- New Mexico State Library offered a series of workshops on beyond-thebasics computer skills;

- the Rhode Island office of Library and Information Services established a key partnership with the Department of Labor and Training to address workforce needs; and

- the Colorado State L-library delivered workshops and webinars to help libraries connect with local entrepreneurs.

Gutsche (2011) makes the argument that library budgets and staff were cut at exactly the time when the demand for their services were increasing. She concludes that, far from being a dispensable resource, libraries are centers of assistance and a potential collaborator in business efforts to obtain qualified staff.

Lyn Piotrowicz and Scott Osgood (Piotrowicz \& Osgood, 2009) detail practical methods for saving costs linked to facilities management. They recommend that librarians become more aware of the physical structure of the buildings in which they work in order to budget more effectively. A few physical changes will provide the library with immediate savings with little initial outlay. These changes do not require any contractors or building managers. Piotrowicz and Osgood (2009) conclude that inexpensive changes such as the following can save money and energy:

- Install programmable thermostats (under $\$ 100$ each).

- Inspect the windows.

- Write a summer/winter rule for using window treatments (blinds, which should be double or triple cellular).

- Have the HVAC units serviced before each season.

- Turn the hot water tank (if the library has one) to $105^{\circ} \mathrm{F}$.

- Inspect the outside of the building to determine which way it is facing and to check for structural cracks.

Librarians Bing Wang and Bruce Henson (Wang \& Henson, 2011) report that many academic libraries are combining reference and access services at a single service location. Their institution, the Georgia Institute of Technology Library and Information Center, has been working on a Combined Services Area Project to transform service points into a one-stop area. The services to be combined are reference, circulation, and technology support (Wang 
\& Henson, 2011). The project's budget covers both staff development and physical layout design, as well as federal grant submissions, reference department relocation, and career staff relocation. The authors include an example of a project progress summary. This type of streamlined reorganization is an important step toward providing more cost-efficient library services.

Libraries have the potential to be important sources of educational materials and instruction. Lark Birdsong and Jennifer Freitas (2012) report that the University of Washington Information School provides services to adult learners searching for "just-in-time" education, rather than academic credit. Taught by librarians, these courses are similar to information literacy classes. Training programs can be developed that emphasize practical information gathering skills for business, health, and daily applications (Birdsong \& Freitas, 2012). Similar to public library instruction, the UW courses are intended to reach populations outside of the traditional academic environment (that need either first time training or refresher courses in new technologies). Examples include health care seekers, adults over 50, patrons without jobs, women without homes, and members of youth programs.

Lindsy Dillingham (2012) explores the impact of an economic recession on library communication and finds that during a recession communication spending is often cut as a budget management strategy. She suggests that eliminating these sorts of expenditures can actually make the effects of a recession worse. In agreement with Gutsche, Dillingham (2012) emphasizes the "dichotomous pattern" of library reductions at the time when the need for them is increasing due to economic circumstances. She proposes that a class on developing information centers specifically during a recession should be added to the LIS (Library and Information Science) graduate curriculum. Because recessions inevitably occur as part of the U.S. economic cycle, libraries and information centers should anticipate the effects of recessions and have programs in place to assist the effected population segments. In the profit-driven corporate sector, financial administrators, bank managers, and corporate librarians should be made aware of the importance of information spending for lessening the effects of economic crises.

When libraries lose a significant percentage of their budgets they undergo a crisis. Michael Hargis and John Watt (2010) define crises as events that disrupt the normal operation of an organization and recommend a framework for overcoming such disruptions. The framework includes the use of life-cycle models which emphasize that organizations grow and succeed depending upon how they navigate the cyclical nature of these events. The authors present a list of challenging scenarios that include the collapse of financial markets, irresponsible corporate decisions, and fraud/liability cases. They point out that the various causes and consequences of these scenarios highlight the complexity of effective change-management. The authors emphasize that the perception of an organization's effectiveness and utility is critical in successful navigation and recovery. They conclude that every 
organization should have a response plan for likely to recur crises, such as economic recessions. The plan should include tactics for perceptionmanagement and be updated on a regular basis. In a library context the strategic plan functions as the response plan and perception-management serves as a useful tool marketing and soliciting donors.

Frank Allen and Mark Dickie (2007) emphasize that haphazard and subjective (their terms) funding mechanisms can impair short-term and longterm planning. They recommend formula-based budgets in order to promote stability and guard against budget cuts, and they contend that a library's budget is less susceptible to economic and political fortunes if it is program driven. They offer a model that depends upon quantifiably objective institutional characteristics of a library's environment. The model proposes funding strategies be based upon measurable inputs thereby strengthening and adding validity to a librarian's case for a better share of a university's budget. Although their example is the academic library, Allen and Dickie's advice applies to other types of libraries. Budgets that are program or goal oriented have the potential to shield all libraries from reductions in allocations.

In Libraries at the Crossroads John Horrigan (2015) examines a recent Pew Research Center survey about what the public wants and expects from public libraries. The survey found a complex mixture of patron attitudes toward what libraries should become. He suggests that the slight decline in library attendance in the last three years may be due to the higher than average use of libraries during the height of the recession. Some of the responses that call for more participation from libraries in a societal context include:

- Low-income Americans, Hispanics and African Americans are more likely than others to say that a library closing would impact their lives and communities.

- Large majorities of Americans see libraries as part of the educational ecosystem and as resources for promoting digital and information literacy.

- Many believe libraries should be pathways to economic opportunity, especially when it comes to providing resources for business development, jobs search, and enhancing work force skills.

- 74\% of Americans ages 16 and older think libraries should "definitely" offer programs for active duty military personnel or veterans.

- $73 \%$ of all those ages 16 and over say libraries contribute to people finding the health information they need.

Finally, almost a third of all Americans say that closing their local public library would have a major impact on the family (Horrigan, 2015).

These articles were selected because of their fundamental agreement about the importance of organizational planning. The authors provide prac- 
tical advice on how to manage resources; evidence that library use increased during the recession; plans for cost efficient combined services; and the opinions of many patrons that libraries should take an active role in helping them to achieve personal goals. Clearly, the basic elements of a strategic plan for any organization should anticipate changes and threats in the outside environment. Once the fundamental objectives are determined, they can be described as goals and fit into a preliminary schema, such as a table, chart, or blueprint.

\section{BLUEPRINT FOR STRATEGIC PLANNING}

Given the changing nature of information center environments, it is important for library administrators and others who share responsibility for the library's operation to think strategically about organizational goals. The means by which a library responds to external forces are codified and given the status of rules by stated goals. Goals can be understood as heuristic guidelines (in the sense of practical recommendations) for actualizing the vision and mission statements. Traditionally, these statements are used as the formal documents that define an organization. A strategic plan is then developed that lays the groundwork for the process of change. Plans of this type should undergo evaluation at least annually to ensure the progress of the goals. In Table 1, specific actions have been matched with the relevant goals and criteria for evaluating success. The table can be understood as a blueprint for vision, mission, and other planning statements, because it lists the specific content of a budget justification, rather than implying the importance of what the organization will achieve. Using vague homilies about the excellence or satisfactions of a program rather than goals-oriented projects leaves open the potential for deception. Strategic implementation of a plan based upon this type of blueprint ensures that patrons will be provided the ways and the means to improve their current status if they take advantage of the services offered. The final assessment of implementation is whether a library or information center has added value to the lives of those who utilized its services. This value can take the form of new employment, increased earning power, health insurance coverage, and better information literacy skills.

The practical and verifiable nature of the goals in this blueprint prevents the possibility of there being a difference between stated goals and real goals. Hidden motives, which often involve financial considerations, may influence the way goals are expressed in a strategic plan. For example, the stated goal to decrease the evening hours of a library in order to better serve the daytime community may have as its real motivation the transfer of funds from one unit, such as circulation, to another, such as administration. The transparency of the above goals is a direct consequence of their service-oriented character. 
TABLE 1 Goals, Actions, and Success Criteria chart as a blueprint for strategic planning. This example is best suited for medium to large public libraries.

\begin{tabular}{|c|c|c|}
\hline Goals & Actions & Success Criteria \\
\hline $\begin{array}{l}\text { Library is effective at } \\
\text { assisting patrons with job } \\
\text { search. }\end{array}$ & $\begin{array}{l}\text { - Partner with local } \\
\text { businesses to provide job } \\
\text { referral services. } \\
\text { - Provide instruction classes } \\
\text { for basic Web site } \\
\text { development and resume } \\
\text { writing }\end{array}$ & $\begin{array}{l}\text { - Businesses report vacancies } \\
\text { filled by patrons. } \\
\text { - Participants report } \\
\text { improvement in these skills. }\end{array}$ \\
\hline $\begin{array}{l}\text { Library has the resources for } \\
\text { improving patron's basic } \\
\text { English comprehension } \\
\text { and providing Internet } \\
\text { service. }\end{array}$ & $\begin{array}{l}\text { - Provide literacy classes } \\
\text { based on ESOL content at } \\
\text { established times. } \\
\text { - Provide computer work } \\
\text { stations and free WiFi } \\
\text { service. }\end{array}$ & $\begin{array}{l}\text { - Participants improve basic } \\
\text { English communication skills. } \\
\text { - Patrons access Internet for } \\
\text { personal goals. }\end{array}$ \\
\hline $\begin{array}{l}\text { Library is a dependable } \\
\text { source for tax and } \\
\text { healthcare information. }\end{array}$ & $\begin{array}{l}\text { - Provide tax forms and } \\
\text { booklets. } \\
\text { - Provide insurance forms } \\
\text { and healthcare } \\
\text { marketplace information } \\
\text { and Web site. }\end{array}$ & $\begin{array}{l}\text { - Patrons use forms and } \\
\text { booklets. } \\
\text { - Internet logs show patron } \\
\text { sign ups to healthcare.gov } \\
\text { and other insurance sites. }\end{array}$ \\
\hline $\begin{array}{l}\text { Library is a place where } \\
\text { families want to } \\
\text { frequently visit. }\end{array}$ & $\begin{array}{l}\text { - Provide safe, clean } \\
\text { furniture and } \\
\text { surroundings for patron } \\
\text { use. } \\
\text { - Enclose youth collection } \\
\text { area to allow children and } \\
\text { youth activities without } \\
\text { disturbing other patrons. }\end{array}$ & $\begin{array}{l}\text { - Questionnaire asking if } \\
\text { patrons find facility safe and } \\
\text { clean is answered } \\
\text { affirmatively } \\
\text { - Youth activities are popular } \\
\text { and other patrons report no } \\
\text { noise complaints. }\end{array}$ \\
\hline $\begin{array}{l}\text { Library is a center that } \\
\text { provides help material to } \\
\text { senior citizens and } \\
\text { students. }\end{array}$ & $\begin{array}{l}\text { Provide audio equipment } \\
\text { and large print books for } \\
\text { the visually impaired. } \\
\text { - Provide CD roms and } \\
\text { e-books for all of the } \\
\text { college and professional } \\
\text { school entrance exams. }\end{array}$ & $\begin{array}{l}\text { - Blind and visually impaired } \\
\text { patrons use service. } \\
\text { - Students use and check out } \\
\text { CD's and e-books. }\end{array}$ \\
\hline $\begin{array}{l}\text { Professional staff provides } \\
\text { reference assistance for } \\
\text { medical and government } \\
\text { programs, in addition to } \\
\text { general research } \\
\text { questions. }\end{array}$ & $\begin{array}{l}\text { - Train professional staff in } \\
\text { use of medical databases. } \\
\text { - Train professional staff in } \\
\text { use of affordable housing } \\
\text { and food bank Web sites. }\end{array}$ & $\begin{array}{l}\text { - Reference staff are capable of } \\
\text { referring patrons to } \\
\text { appropriate databases. } \\
\text { - Reference staff are capable of } \\
\text { referring patrons to } \\
\text { appropriate Web sites. }\end{array}$ \\
\hline
\end{tabular}

Librarians should become well acquainted with a process that is sometimes not sufficiently emphasized: the marketing of library resources and services. Marketing is necessary for the survival of libraries and for the success of professionals in roles both inside and outside of traditional information venues. The ability to persuade citizens of the value of a service is a key skill that can be used to help libraries flourish in competitive 
environments. Likewise, requests for grants and donations are themselves examples of marketing documents that must convince the targeted audience of the institution's positive qualities.

Real progress toward achieving the goals of a strategic plan can only occur when adequate funding is available. Libraries do not operate a for-profit enterprise and in many ways the mission of public institutions is incompatible with that model. Therefore, in addition to developing strategic plans to justify current funding, librarians should search for grant, donation, and endowment opportunities. Corporations often give donations to strengthen their ties to the local community, and librarians should be aware of the businesses in the area they serve.

\section{CONCLUSION}

Despite perceptions of some lawmakers that libraries are dispensable, studies confirm that during the recent economic downturn the use of library space and materials increased significantly. People in need of help and information found assistance from library staff and resources. Although there has been job loss in the profession, librarians are working to manage change successfully, and conditions are improving. Nevertheless, given the budget restrictions suffered by many library systems, library administrators should have on hand a justification of goals that support strategic plans and mission statements. Clear goals and success criteria are important for attracting endowments and donations and for showing how public institutions can help alleviate difficult economic conditions. There are many citizens who are not able to afford a computer, Internet access or books and will need the library for such services. Libraries are busy places and public interest in them will continue into the foreseeable future.

Information has economic value and the lack of valid information has economic consequences. Libraries are the best tool that governments have for ensuring that low-income and disadvantaged citizens have access to information. These citizens become stakeholders in a library's continued funding and development. A lack of access to valid information can result in loss of educational opportunities, loss of employment, inadequate legal representation, and loss of housing and health benefits. Although library operating budgets are once again on the rise, these permanent threats should never be forgotten (Peet, 2015).

Libraries are currently becoming more of a cultural center for surrounding communities, providing a larger range of services centered on information access and patron assistance. Whether partnering with local businesses, keeping on top of building maintenance, developing classes for practical information-gathering skills, or researching grant opportunities, library professionals continue to demonstrate their enduring value. Many library 
systems are engaging in projects that will combine services and emphasize team structure and are reaching out to their communities in novel ways. Moreover, the desire for places that provide the means for personal enhancement and assistance-something found to be in high demand during hard times - should be respected and developed. After all is said and done, what libraries and information centers are ultimately about is the fulfillment of human aspirations and hope.

\section{REFERENCES}

Allen, F., \& Dickie, M. (2007). Towards a formula-based model for academic library funding: Statistical significance and implications of a model based upon institutional characteristics. College \& Research Libraries, 68(2), 170-181.

Birdsong, L., \& Freitas, J. (2012). Helping the non-scholar scholar: Information literacy for lifelong learners. Library Trends, 60(3), 588-610.

Bureau of Labor Statistics. (February 2012). The recession of 2007-2009. Retrieved from http://www.bls.gov/spotlight/2012/recession/pdf/recession_bls_spotlight. pdf

Dillingham, L. (2012). Communicating with bank stakeholders during recession: Why it's important, who is doing it, and how to stay in the loop. Journal of Business E Finance Librarianship, 17(4), 313-327.

Gutsche, B. (2011). A boon to the workforce. Library Journal, 136(14), 28-31.

Hargis, M., \& Watt, J. (2010). Organizational perception management: A framework to overcome crises events. Organization Development Journal, 28(1), 73-87.

Horrigan, J. (2015). Libraries at the Crossroads. Pew Charitable Trusts. Retrieved from http://www.pewinternet.org/2015/09/15/libraries-at-the-crossroads

Kelly, M. (2011). Bottoming out? Library Journal, 136(1), 28-31.

Landau, H. B. (2011). Winning library grants: A game plan. Chicago: ALA (pp. 98-103).

Piotrowicz, L., \& Osgood, S. (2009). Building science 101. American Libraries, 40(4), $56-58$.

Peet, L. (2015). Paying for people. Library Journal, 140(2), 30-32.

Perceptions of libraries, 2010: Context and community. (2010). Retrieved from https://www.oclc.org/reports/2010perceptions.en.htm.

Project Compass-WebJunction. Retrieved from www.webjunction.org/exploretopics/project-compass.html.

Strietfeld, D. (2010). Anger as a private company takes over libraries. The New York Times. Retrieved from www.nytimes.com/2010/09/27/business/27libraries.html

Wang, B., \& Henson, B. (2011). Change is coming: A combined services area project. Science \& Technology Libraries, 30(1), 89-98. 